\title{
Application of DNA Fingerprints for Identification and Genetic Analyses of Mango (Mangifera indica) Genotypes
}

\author{
A. Adato, D. Sharon, and U. Lavi ${ }^{1}$ \\ Department of Fruit Tree, Genetics, and Breeding, Agricultural Research Organization, P.O. Box 6, \\ Bet-Dagan 50250, Israel
}

J. Hillel ${ }^{2}$ and S. Gazit ${ }^{3}$

Faculty of Agriculture, The Hebrew University of Jerusalem, P.O. Box 12 Rehovot 76100, Israel

Additional index words. breeding, DNA markers, genetic relatedness, minisatellites

\begin{abstract}
DNA fingerprint information was used for identification of mango (Mangifera indica L.) cultivars for genetic relatedness analysis of 20 mango cultivars and for genetic analysis of a family structure. Genomic DNA was extracted from young leaves, digested with Hind III or Dra I, and hybridized with 10 different DNA probes. Jeffreys' minisatellite probe 33.6 was the most useful, resulting in well-resolved bands representing highly polymorphic loci. Specific patterns were obtained for each cultivar. The probability of obtaining a similar pattern for two different cultivars was $9.4 \times 10^{-6}$. Based on DNA fingerprint information, genetic distances between 20 mango cultivars were evaluated and an evolutionary tree was established. Analysis of DNA fingerprint band patterns of 12 progeny resulting from a cross between 'Tommy Atkins' and 'Keitt' mango revealed neither linked nor allelic bands. Application of the reported results for identification, genetic analyses, and mango breeding is discussed.
\end{abstract}

Classical approaches for the identification of mango cultivars are based on morphological traits (Singh, 1969). The evaluation of these traits is subjective and their assessment is difficult. Recently, isozyme analysis has been used to identify mango cultivars and to decipher their parentage (Degani et al., 1990, 1992). However, isozyme polymorphism is limited, hence limiting its ability to identify cultivars.

Mini- and microsatellite DNA markers are highly polymorphic in many species due to a variable number of tandem repeats (Dallas, 1988; Hillel et al., 1989, 1992; Jeffreys and Morton, 1987; Jeffreys et al., 1985a, 1985b; Lavi et al., 1991; Numberg et al., 1989; Nybom and Schaal, 1990). DNA fingerprints obtained by hybridization of mini- and microsatellite probes with genomic DNA were shown to be useful for cultivar identification (Lavi et al., 1991; Nybom and Schaal, 1990; Sharon et al., 1992), as well as for genetic and evolutionary analyses (Dunnington et al., 1991; Kuhnlein et al., 1989; Lavi et al., 1991). The advantage of using DNA fingerprints, rather than other genetic markers such as isozymes (Degani et al., 1990, 1992) and restriction fragment length polymorphisms (RFLP) (Gebhardt and Salamini, 1992), for identification and genetic analyses stems from the fact that this technique allows simultaneous detection of many polymorphic loci, with one or few multilocus probes. In this study, DNA fingerprint information was used for identification and genetic analyses of mango cultivars.

Received for publication 31 May 1994. Accepted for publication 21 Sept. 1994. Contribution from the Agricultural Research Organization, The Volcani Center, Bet-Dagan, Israel. No 1336-E, 1994 series. The oligonucleotide probes are subject to patent application. Commercial inquiries should be directed to FRESENIUS AG, Oberursel, Germany. The authors thank J. T. Epplen for providing the oligonucleotide probes and A.J. Jeffreys for providing 33.6 and 33.15 probes. The cost of publishing this paper was defrayed in part by the payment of page charges. Under postalregulations, this paper therefore must be hereby marked advertisement solely to indicate this fact.

'To whom reprint requests should be addressed.

${ }^{2}$ Dept. of Genetics.

${ }^{3}$ Dept. of Horticulture.

\section{Materials and Methods}

Plant material. Young leaves were obtained from 27 mango cultivars selected for fruit production ('Brindinbani', 'Carabao', 'Edward', 'Fascel', 'Gaylour', 'Gedong', 'Glenn', 'Haden', 'Irwin', 'Jubilly', 'Keitt', 'Kent', 'Lily', 'Lippens', 'Maya', 'Mistikawi', 'Pairi', 'Palmer', 'Parvin', 'Pica', 'Tahar', 'Tommy-Atkins', '1/ 5 ', '6/6', '16/36', '20/1', and '20/26') and from 14 mango cultivars selected as rootstock ('Besor-7/32', 'Gomera-1', 'Ein-Yahav-4', 'F-7-2', 'F-15-11') 'Saber', 'Turpentine', 'Warburg', 'Yotvata-8', 'Yotvata-142', 'Yotvata-191', 'Yasmin', '4/9', and '13/1'). Leaves were also collected from 15 seedlings of 'Tommy Atkins' that was caged with 'Keitt' under a net cage in the presence of a beehive.

DNA isolation. DNA was isolated from young leaves as described by Murray and Thompson (1980), with the following modifications. The extraction buffer consisted of $2 \%$ hexadecyltrimethyl ammonium bromide (CTAB); $0.1 \mathrm{M}$ tris- $\mathrm{HCl}, \mathrm{pH} 8 ; 0.02 \mathrm{M}$ ethylenediamine tetra acetic acid (EDTA); $1.4 \mathrm{M} \mathrm{NaCl}$, and $1 \% \beta-$ mercaptoethanol. After three chloroform extractions, two volumes of precipitation buffer (1\% CTAB; $0.05 \mathrm{~m}$ tris- $\mathrm{HCl}, \mathrm{pH} 8 ; 0.01 \mathrm{~m}$ EDTA; and $1 \% \beta$ - mercaptoethanol) were added to the aqueous phase. The nucleic acids were dissolved in $1 \mathrm{M} \mathrm{CsCl}$, precipitated with ethanol, and redissolved in water. Phenol, phenol-chloroform, and chloroform extractions were preformed and the nucleic acids were precipitated with ethanol and dissolved in TE buffer (10 $\mathrm{mm}$ tris-HCl, $\mathrm{pH} 8$, and 1 mM EDTA).

DNA fingerprinting (DFP). Ten micrograms of DNA was digested with Hind III or Dra I restriction endonuclease according to the recommendations of the manufacturer (New England Biolabs, Beverly, Mass.). Electrophoresis was carried out on a 20-cm-long $0.8 \%$ agarose gel in TBE $(0.045 \mathrm{~m}$ tris-borate and $0.001 \mathrm{~m}$ EDTA, $\mathrm{pH} 8)$ at $1.5 \mathrm{~V} / \mathrm{cm}$ for $40 \mathrm{~h}$. Cultivar and rootstock DNAs were electrophoresed on separate gels. Gels were capillary blotted onto Hybond-N+ membranes (Amersham International, Amersham, U.K.). Lambda DNA Hind III fragments (New England Biolabs) served as size markers.

Membranes were hybridized to the inserts of Jeffreys' 
minisatellite probes 33.6 and 33.15 (Jeffreys et al., 1985a), to the whole bacteriophage M13 (Vassart et al., 1987), to R18.1 [a cattle genomic clone that contains (GT), islands (Haberfeld et al., 1991)], to 22.3 (a 2-kb probe that includes probe R18.1), and to simplerepeat oligonucleotide probes $(\mathrm{GGAT})_{4},(\mathrm{GTG})_{5},(\mathrm{GATA})_{4}$, $(\mathrm{GACA})_{4}$, and (AAC) $)_{5}$. Jeffreys' probes (33.6 and 33.15), R.18.1, and 22.3 were labeled with $\alpha-{ }^{32} \mathrm{P}$ dCTP by random priming (Feinberg and Vogelstein, 1983), and simple-repeat oligonucleotide probes were 5 '-end labeled with $\gamma-{ }^{32} \mathrm{P}$ dATP by T4-DNA kinase reaction (Fritsch et al., 1989).

Prehybridization and hybridization of the genomic probes were preformed at $65 \mathrm{C}$, those of the simple-repeat probe $(\mathrm{GTG})_{5}$ at $45 \mathrm{C}$, probes $(\mathrm{GGAT})_{4}$ and $(\mathrm{GACA})_{4}$ at $43 \mathrm{C}$, and probes $(\mathrm{GATA})_{4}$ and $(\mathrm{AAC})_{5}$ at $35 \mathrm{C}$. Prehybridization for 3 to $5 \mathrm{~h}$ and hybridization for $16 \mathrm{~h}$ were carried out in $0.263 \mathrm{M} \mathrm{Na}_{2} \mathrm{HPO}_{4}$ buffer with $7 \%$ sodium dodecyl sulfate (SDS), $1 \mathrm{~mm}$ EDTA, and $1 \%$ bovine serum albumin (BSA). Membranes were washed at the hybridization temperature with $0.263 \mathrm{M} \mathrm{Na}_{2} \mathrm{HPO}_{4}$ and $1 \%$ SDS for $20 \mathrm{~min}$, then twice with $2 x$ saline sodium citrate (SSC), and with $0.1 \%$ SDS for 20 min each and twice with $1 \times$ SSC and $0.1 \%$ SDS for 20 min each. For hybridizations with the probe 33.6, washes stopped after the first 2x SSC and 0.1\% SDS wash. For hybridizations with the M13 probe, the first wash was as described above, followed by a wash in $4 \mathrm{x}$ SSC and $0.1 \% \mathrm{SDS}$ at room temperature for $20 \mathrm{~min}$ (in this hybridization higher stringency would have caused loss of possible band pattern). For hybridizations with the simple-repeat sequences, the first wash was as described above followed by two washes in $4 \mathrm{x}$ SSC and $0.1 \%$ SDS in hybridization temperature. Membranes were autoradiographed with Agfa X-ray film for 1 to 10 days at $-80 \mathrm{C}$ with intensifying screens.

Analysis of DNA fingerprint patterns. Comparison and analysis were carried out on DFP patterns obtained on the same gel. The autoradiograms were scanned by laser densitometer (Molecular Dynamics, Sunnyvale, Calif.) and analyzed using Image-Quant software (Molecular Dynamics). Genetic distance (d) values between cultivars were calculated, based on band sharing and the statistical probability for mutation in the restriction site, using the software Evol-Tree (Masatoshi and Wen-Hsiung, 1979). Rank correlations were calculated between d values obtained by various probes according to Snedecor (1956). Band-sharing (BS) levels (twice the number of the common bands divided by the total number of bands observed in two lanes) and the determination of complete linkage and allelic relationships between bands were carried out according to Hillel et al., (1989). Analyses were carried out on samples run on the same gel only. The probability $(P)$ of two individuals having the same DNA fingerprint pattern was calculated as described by Jeffreys et al. (1985b): $P=(B S)^{\mathrm{n}}$, where BS is the average BS levels between pairs of cultivars on a gel detected by the probes and $n$ is the average number of bands per individual detected by the probes. Transmission frequency was calculated as described by Jeffreys et al. (1986). The total number of potentially detectable loci was calculated according to Hillel et al. (1989).

\section{Results}

DNA fingerprints of mango cultivars and rootstocks. Genomic DNA of 26 mango cultivars and 14 mango rootstocks probed with 33.6, R18.1, 22.3, (GGAT), (GTG), and (GATA) $)_{4}$ revealed resolvable and complex band patterns. Analyses presented below are based on DNA fragments ranging in size from 2 to $20 \mathrm{~kb}$. The DNA fragments detected by probe 33.6 were the most polymorphic. DNA samples digested with Hind III endonuclease had an average of five specific bands and an average of 55\% BS between mango cultivars (Table 1). Using the same probe, DNA samples digested with Dra I endonuclease had an average of seven specific bands and an average of $52 \%$ BS (Fig. 1). DFP patterns of mango cultivars and rootstocks revealed high polymorphism between unrelated cultivars. Related cultivars exhibited higher level of BS than the average BS between cultivars; 'Pica' and 'Carabao', two similar cultivars introduced from the Philippines, digested with Hind 111 and hybridized to probe 33.6, showed a BS of $83 \%$ that is higher than the average BS of 55\%. The rootstocks 'Yasmin', 'Besore-7/32', and 'F-15-11', which are offspring of ' $13 / 1$ ', digested with Dra I and hybridized to probe 33.6, showed an average BS of $60 \%$ that is higher than the average BS of $52 \%$. Each cultivar or rootstock can be identified by its DFP pattern. The probability of two unrelated cultivars and rootstocks having the same pattern is $8 \times 10^{\prime \prime}$ and $1.2 \times 10^{-5}$, respectively. The presence of many specific bands and low levels of BS between cultivars reflects the high level of informativeness of probe 33.6. The patterns revealed by $(\text { GGAT) })_{4}$ and (GATA) ${ }_{4}$ showed lower levels of polymorphisms, with an average BS of $75 \%$ and $86 \%$ respectively (Table 1 ). The loci detected by other microsatellites were of low polymorphism.

Genetic relatedness analysis. The DNA of 20 cultivars, digested with Dra I , was hybridized to Jeffreys' probe 33.6 and to simple-repeat probes $\left(\right.$ GGAT) ${ }_{4}$ and $(\text { GATA) })_{4}$. The DFP patterns revealed by these hybridizations were scanned and $d$ values between cultivars were evaluated (Table 2). Different probes gave different absolute d values. Average and range of d values calculated according to the different probes are given in Table 3 . However, the genetic relatedness between cultivars as reflected by these $d$ values remained usually the same. Genetic relatedness and more available information are given in Table 4. Rank correlations calculated between $\mathrm{d}$ values of different probes were all higher than $0.7(P<0.01)$. When different probes reflected different relatedness between cultivars, the relatedness chosen was the one obtained based on at least two out of three probes. Knowledge about origin and history of cultivars from the Floridian group (including mango cultivars that have been selected in Florida during the last century) was based on Campbell (1992). An evolutionary tree, demonstrating the relationships between cultivars from this group, was established according to the calculated

Table 1. Number of scoreable bands per individual $(\mathrm{N})$, standard error $( \pm \mathrm{SE})$, number of specific bands $(\mathrm{S})$, and level of band sharing (BS) among mango cultivars. DNA was digested with various restriction enzymes (Hind III, Dra I, and Eco RI) and hybridized to probe 33.6, or was digested with Dra I and hybridized to various probes $\left[33.6,(\text { GGAT })_{4}\right.$, and $\left.(\text { GATA })_{4}\right]$.

\begin{tabular}{lccccc}
\hline \hline & \multicolumn{3}{c}{ Restriction enzyme } & \multicolumn{2}{c}{ Probe } \\
\cline { 2 - 6 } Criterion & Hind III & Dra I & Eco RI & 33.6 & $($ GGAT) \\
\hline $\mathrm{N} \pm$ SE & $15 \pm 4$ & $1.5 \pm 3$ & $10 \pm 1$ & $15 \pm 3$ & $29 \pm 2$ \\
$\mathrm{~S} \pm$ SE & $5 \pm 3$ & $7 \pm 3$ & $1 \pm 1$ & $5 \pm 2$ & $23 \pm 1$ \\
Range in S & $1-15$ & $1-13$ & $0-2$ & $3 \pm 1$ & $0-14$ \\
BS (\%) \pm SE & $55 \pm 13$ & $52 \pm 11$ & $88 \pm 2$ & $52 \pm 11$ & $75 \pm 2$ \\
\hline
\end{tabular}

${ }^{\overline{ }}$ The data of these columns are the same. 


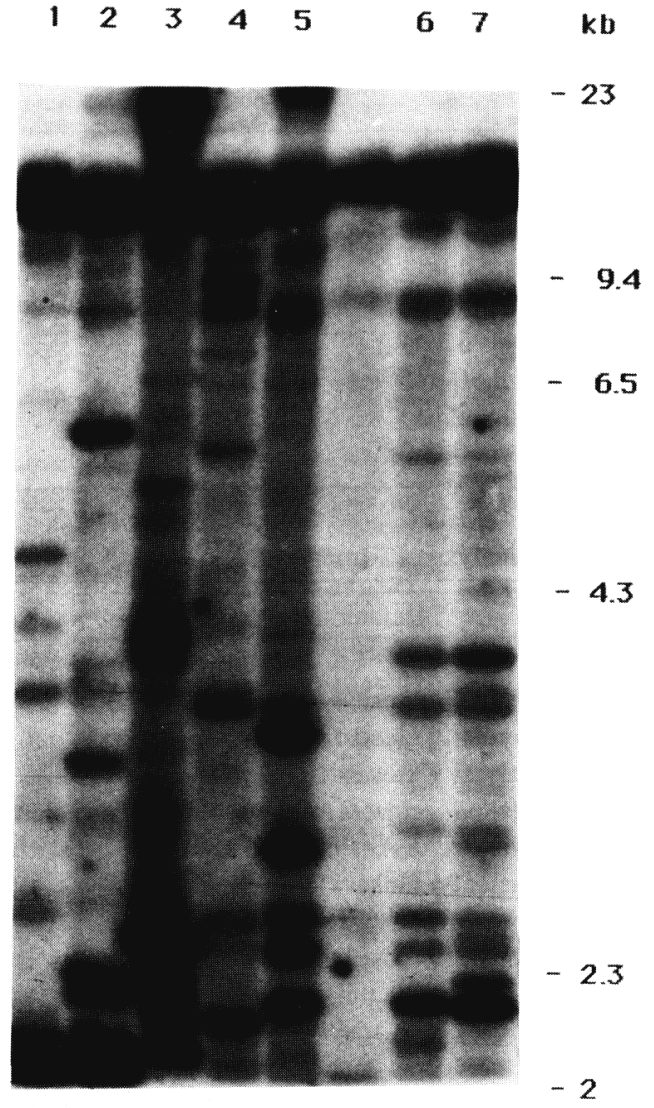

Fig. 1. DNA fingerprints of mango cultivars, digested with Dra I endonuclease and hybridized to probe 33.6. Size markers are given in kilobase. Lanes are as follows: 1 = 'Pairi', 2 = 'Mistikawi', 3 = 'Brindibani', 4 = 'Carabao', 5- 'Haden', 6 = 'Kent', 7 = '20/26'.

genetic distances (Fig. 2). The d values between progeny and their known parent were significantly lower than the average d values.

Genetic analysis. Genetic analysis was carried out on offspring of a 'Tommy Atkins' and 'Keitt' cross. DNA was digested with Hind III and hybridized to Jeffreys' probe 33.6 . DFP patterns of six offspring and parents are presented in Fig. 3. A total of 27 parental bands were detected by probe 33.6, of which 16 were polymorphic (BS is $41.4 \%$ ). The paternal contribution was 11 bands, of which 6 were polymorphic. The maternal contribution was 16 bands, of which 10 were polymorphic. The patterns of 12 seedlings of the 15 examined included bands that originated in either 'Tommy Atkins' or 'Keitt' band patterns. The pattern of one seedling included one new band that could not be detected in either 'Tommy Atkins' or 'Keitt' patterns. The patterns of two seedlings included bands that could be detected only in 'Tommy Atkins' pattern. The average transmission frequency (Jeffreys et al., 1986) detected in this analysis was $65 \%$ for maternal specific bands and $31 \%$ for paternal specific bands. One paternal band did not appear in any of the 12 progeny. No pair of bands was found to be completely linked, and no band was found to be allelic to another band. Partial linkage was found among maternal polymorphic bands: two maternal bands could be partially linked to one of three other bands with recombination frequency of $14.5 \%$, another band could be partially linked to one of three other bands with recombination frequency of $21 \%$. No polymorphic band seemed to be homozygous (none of the parental polymorphic bands appeared in all progeny). The total number of potentially detectable parental loci cannot be estimated because no allelic pair of polymorphic bands was observed (Hillel et al., 1989).

\section{Discussion}

Application of DNA fingerprints (DFP) markers for identification of mango cultivars shed light on some horticultural dilemmas. It is widely accepted that 'Edward' resulted from a cross between 'Haden' and 'Carabao' (Campbell, 1992). Isozymic evidence (Degany et al., 1990) showed that 'Carabao' cannot be a parent of 'Edward'. The DFP patterns obtained in this work by hybridization to Jeffreys' probe 33.6 confirmed the isozymic conclusion. The BS between the pairs 'Edward'-'Haden' and 'Edward'-'Carabao' is $80 \%$ and $54 \%$ respectively. However, the DFP patterns of these two cultivars show that 'Edward' cannot be their progeny.

' $6 / 6$ ' is known as a seedling of 'Irwin', while the pollen donor parent is unknown (Slor and Gazit, 1982). According to isozymic analysis of six different enzyme systems, any one of ten different cultivars could have been the pollen donor parent of '6/6' (Degani et al., 1990). DFP patterns of these ten cultivars, resulting from hybridization with probe 33.6, reveal that only 'Maya' can be the pollen donor parent of '6/6'. Maya' was indeed present in the orchard where the seeds of 'Irwin' were obtained (Slor and Gazit, 1982).

'Turpentine', a Floridian cultivar, looks morphologically similar to '4/9', a rootstock that was introduced to Israel from Kenya. The DFP patterns of these two rootstocks revealed by hybridization to probe 33.6 differ in four bands, although having high BS of $81 \%$.

The rootstock '13/1', introduced to Israel from Egypt (Gazit and Kadman, 1980), is polyembryonic with $-15 \%$ zygotic seed-

Table 2. Genetic distance values ( $\mathrm{d}$ x 100) of 12 cultivars from the Floridian group based on band sharing of DNA digested with Dra I and hybridized to 33.6 .

\begin{tabular}{|c|c|c|c|c|c|c|c|c|c|c|c|c|}
\hline Cultivar & Fascel & Glenn & Haden & Irwin & Keitt & Kent & Lily & Lippens & Maya & Parvin & Turpentine & $6 / 6$ \\
\hline Edward & 3.53 & 2.13 & 0.94 & 2.08 & 3.34 & 3.45 & 3.31 & 3.25 & 2.87 & 2.71 & 5.23 & 2.70 \\
\hline Fascel & & 1.43 & 2.33 & 4.48 & 3.01 & 2.33 & 1.17 & 2.67 & 3.32 & 1.12 & 2.67 & 1.85 \\
\hline Glenn & & & 1.57 & 2.10 & 3.88 & 2.70 & 4.06 & 3.15 & 3.88 & 1.69 & 2.71 & 1.64 \\
\hline Haden & & & & 2.87 & 3.06 & 3.07 & 3.37 & 3.06 & 2.20 & 3.06 & 5.23 & 2.13 \\
\hline Irwin & & & & & 2.75 & 3.32 & 3.53 & 3.37 & 2.71 & 3.46 & 2.10 & 1.49 \\
\hline Keitt & & & & & & 3.26 & 2.52 & 1.52 & 2.13 & 3.32 & 2.15 & 1.69 \\
\hline Kent & & & & & & & 3.34 & 3.37 & 3.31 & 2.75 & 3.06 & 2.12 \\
\hline Lily & & & & & & & & 2.33 & 3.06 & 2.52 & 2.54 & 2.14 \\
\hline Lippens & & & & & & & & & 2.52 & 1.99 & 2.52 & 2.14 \\
\hline Maya & & & & & & & & & & 3.25 & 3.88 & 1.52 \\
\hline Parvin & & & & & & & & & & & 2.67 & 3.25 \\
\hline Turpentine & & & & & & & & & & & & 2.14 \\
\hline
\end{tabular}


Table 3. Average $(A)$ and range $(R)$ of genetic distance $(d \times 100)$ values of cultivars within and between three mango groups. The $d$ values were evaluated based on DNA fingerprints revealed by the probes 33.6, (GGAT) $)_{4}$, and (GATA) ${ }_{4}$

\begin{tabular}{|c|c|c|c|c|}
\hline \multirow[b]{2}{*}{ Group } & & \multicolumn{3}{|c|}{ Probe } \\
\hline & & 33.6 & $(\mathrm{GGAT})_{4}$ & $(\text { GATA })_{4}$ \\
\hline \multirow[t]{2}{*}{ Within cultivars, Floridian group } & $\mathrm{A}$ & 2.42 & 2.65 & 0.70 \\
\hline & $\mathrm{R}$ & $0.94-3.30$ & $1.50-3.50$ & $0.11-1.20$ \\
\hline \multirow[t]{2}{*}{ Within cultivars, Indian and Egyptian groups } & A & 4.05 & 4.20 & 0.83 \\
\hline & $\mathrm{R}$ & $3.14-4.22$ & $3.05-4.33$ & $0.11-1.44$ \\
\hline \multirow[t]{2}{*}{ Between cultivars, Floridian to Indian and Egyptian groups } & $\mathrm{A}$ & 5.17 & 5.23 & 0.85 \\
\hline & $\mathrm{R}$ & $3.70-6,50$ & $3.30-6.64$ & $0.35-1.46$ \\
\hline \multirow[t]{2}{*}{ Between 'Carabao' (Philippinian) to Indian and Egyptian group } & A & 6.70 & 6.90 & 0.96 \\
\hline & $\mathrm{R}$ & $5.50-8.00$ & $4.30-8.70$ & $0.51-1.55$ \\
\hline
\end{tabular}

Table 4. Available information and genetic relatedness based on the genetic distance $(\mathrm{d} \times 100)$ values analysis of 20 mango cultivars of different origin groups.

\begin{tabular}{|c|c|c|}
\hline Cultivar & Available information & Belatedness based on DFP analysis \\
\hline \multicolumn{3}{|c|}{ Floridian } \\
\hline Edward & Known as a seedling of Haden. & Genetically closest to Haden. \\
\hline Glenn & Known as a seedling of Haden. & Genetically closest to the Fascel-Parvin pair. \\
\hline Fascel & Known as an offspring of Haden and Brooks. & Genetically closest to Parvin. \\
\hline Haden & $\begin{array}{l}\text { Molgoba's seedling. Turpentine is suggested to be its } \\
\text { pollen donor parent. }\end{array}$ & $\begin{array}{l}\text { Genetically closest to Edward. Based on at least one probe, } \\
\text { the genetic distance from Turpentine is relatively high. } \\
\text { Genetically closest to } 6 / 6 \text {. }\end{array}$ \\
\hline Irwin & \multicolumn{2}{|l|}{ Known as a seedling of Lippens. } \\
\hline Keitt & $\begin{array}{l}\text { Molgoba's seedling First planted in 1939, Turpentine is suggested } \\
\text { to be its pollen donor parent. According to isozymic analysis of } \\
\text { six enzyme systems it could not be a progeny of a cross } \\
\text { between Molgoba and Turpentine (Degany et al, 1990). }\end{array}$ & $\begin{array}{l}\text { Genetically closest to Lily and to Lippens. Based on at } \\
\text { least one probe the genetic distance from Turpentine is } \\
\text { relatively high. }\end{array}$ \\
\hline Kent & Known as a seedling of Brooks. & $\begin{array}{l}\text { Genetically closest to } 20 / 26 \text { and to the group of Fascel- } \\
\text { Parvin-Glenn. }\end{array}$ \\
\hline Lily & A seedling of unknown parentage. & Genetically closest to Keitt and to Lippens. \\
\hline Lippens & Known as a seedling of Haden. First planted in 1931. & Genetic.dly closest to Keitt and to Lily. \\
\hline Maya & $\begin{array}{l}\text { A seedling of unknown parentage. First planted } \mathrm{m} \text { Israel } \mathrm{m} \\
\text { 1940. Haden is suggested to be one of its parents. }\end{array}$ & Genetically closest to Haden and its descendants. \\
\hline Parvin & Known as a seedling of Haden. & Genetically closest to Fascel. \\
\hline $6 / 6$ & Known as a seedling of Irwin. & $\begin{array}{l}\text { Genetically closest to Irwin. Seems to be a progeny of an } \\
\text { Irwin-Maya cross. }\end{array}$ \\
\hline \multirow[t]{2}{*}{$20 / 26$} & Known as a seedling of Kent. & $\begin{array}{l}\text { Genetically closest to Kent and to the group of Fascel- } \\
\text { Parvin-Glenn. }\end{array}$ \\
\hline & \multicolumn{2}{|l|}{ Indian and Egyptian } \\
\hline Brindibani & & Genetically closest to Pairi and to Mistikawi. \\
\hline Mistikawi & Egyptian & Genetically closest to Brindibani and to Pairi. \\
\hline Pairi & Indian & Genetically closest to Brindibani and to Mistikawi. \\
\hline Warburg & Egyptian & $\begin{array}{l}\text { Genetically closest to } 13 / 1 \text { and to the group of Mistikawi- } \\
\text { Brindibani-Pairi. }\end{array}$ \\
\hline $13 / 1$ & Egyptian, used as a rootstock. & Genetically closest to Warburg. \\
\hline \multicolumn{3}{|c|}{ Philippinian } \\
\hline Carabao & Philippinian & $\begin{array}{l}\text { Genetically closest to Haden and its descendants in the } \\
\text { Floridian group and to Pairi in the Indian and Egyptian } \\
\text { group. }\end{array}$ \\
\hline
\end{tabular}

lings. Current methods do not distinguish reliably between it's nucellar and the sexual seedlings. 'Yasmin', which is a seedling of '13/1' that looks similar to it, may have greater tolerance to high salt and calcareous soils. 'Yasmin' was found to have a unique DFP pattern that differs in four bands from the pattern of $<13 / 1$ '. Nevertheless, there is a high genomic similarity between the two cultivars, indicated by high BS of $84 \%$. 'F-7-2' and 'F- 15-11' are two seedlings of ' $13 / 1$ ' that have been selected under conditions of induced iron deficiency (Shenker, 1989). These two clones look morphologically identical to ' $13 / 1$ ' and have identical isozymic patterns (Shenker, 1989). DFP patterns of 'F-7-2', 'F-15-11' and ' $13 / 1$ ', revealed by hybridization to probe 33.6 , were identical when DNA was digested with Hind III. However, each of these two selections differ in a single band compared with the pattern of '13/ 1 ' when digested with Dra I. This difference could result from self pollination of' $13 / 1$ ' or by a point mutation in a nucellar embryos.

Genetic relationships between 20 mango cultivars were evaluated (Tables 2-4). 'Mulgoba' and 'Brooks' were not available in the current analysis. According to these results and other available information, it seems that 'Keitt' and 'Haden' are not likely to be 


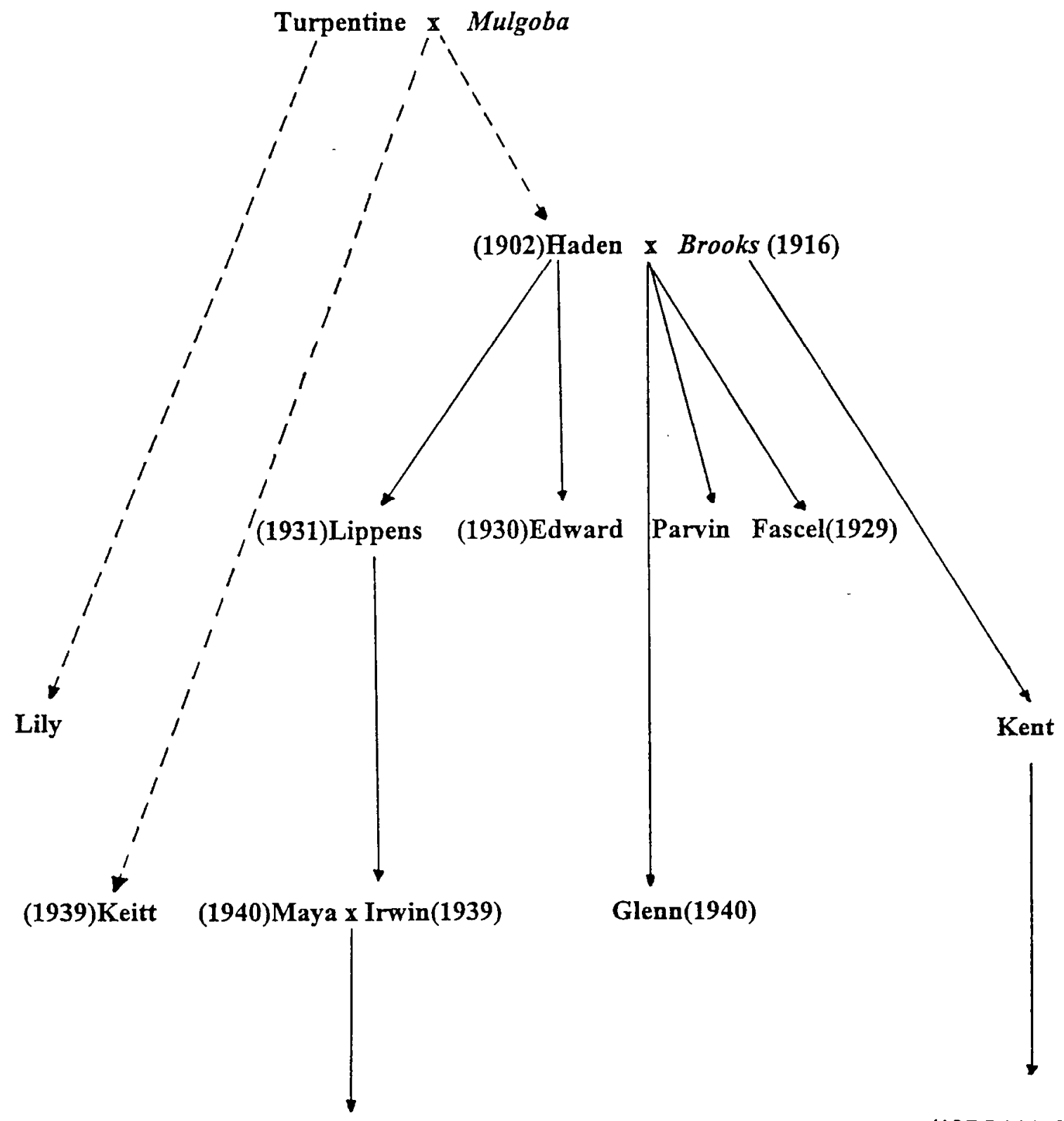

(1971) $6 / 6$

(1976)20/26

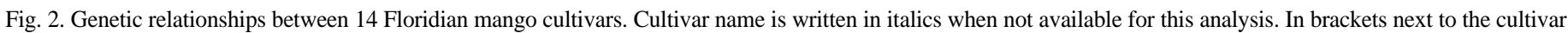
name is the year in which the cultivar was planted. The dashed arrows suggest possible but uncertain relationships.

direct progeny of 'Turpentine'. 'Fascell', 'Parvin', and 'Glenn' are progeny of the same 'Haden'-'Brooks' cross. It seems that 'Lippens' and 'Keitt' are progeny of the same pollen donor crossed with 'Haden' and 'Mulgoba', respectively. According to the d values evaluated in the current research, this pollen donor might be 'Turpentine' or one of it's descendents, which might also be one of 'Lily's' parents. 'Maya' might also be an offspring of 'Haden', as suggested by Oppenheimer (1978).

As expected, in India, which is a primary center of origin for mango, and Egypt (geographically close to India), the genetic variation between cultivars is larger than in Florida, which is a secondary center of origin for mango cultivars.

The relatively high rank correlation calculated between $d$ values that were obtained by different probes indicates that there is a high correlation between the evolution of mango cultivars identified by the probes 33.6, (GGAT), and (GATA). The rank correlation between $d$ values evaluated according to the microsatellite probes $(\mathrm{GGAT})_{4}$ and $(\mathrm{GATA})_{4}, 0.83(\mathrm{P}<0.01)$, was higher than the rank correlations between $\mathrm{d}$ values evaluated according to the 33.6 minisatellite probe and each of the microsatellite probes $(\text { GGAT })_{4}$ and $(\text { GATA })_{4}, 0.7(P<0.01)$ and $0.79(P<0.01)$, respectively.

The pedigree analysis was based on a relatively small group of offspring of a cross between 'Tommy Atkins' and 'Keitt'. Out of a total of 27 detected bands, 16 were polymorphic. The segregation pattern, in which no pair of bands was found to be completely linked, may suggest that most minisatellite loci are not clustered in the mango genome. No allelic pair of bands was detected in the progeny analyzed, similar to previously reported results in other species (Hillel et al., 1989; Jeffreys et al., 1986; Sharon et al., 1992; Tzuri et al., 1991). This may result from comigration of different bands to the same place on the gel or because minisatellite fragments were smaller than the analyzed size range and therefore ran off the gel. None of the parental polymorphic bands appear in 


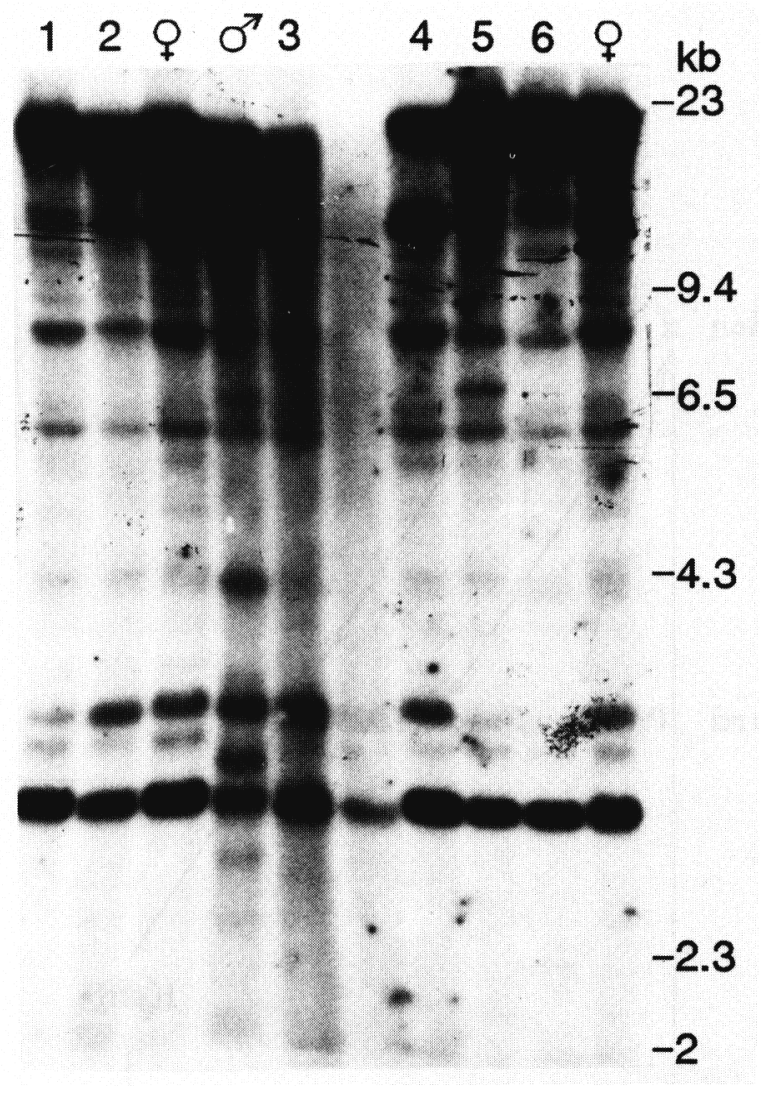

Fig. 3. DNA fingerprints of six mango progeny from a cross between 'Tommy Atkins' as the female parent and 'Keitt' as the pollen donor. Offspring are numbered 1-6. DNA was digested with Hind III, and hybridized to probe 33.6. Size markers are given in kilobase.

all progenies, indicating that none of these bands is homozygote. The patterns of 2 of the 15 seedlings examined included only bands that could be detected in 'Tommy Atkins' pattern; therefore, they seem to be products of a 'Tommy Atkins' self pollination. The pattern of one seedling included one band that could not be detected in 'Tommy Atkins' or 'Keitt' patterns, suggesting that this individual resulted from a cross between 'Tommy Atkins' and another unidentified pollen donor. The patterns of 12 seedlings included bands that could be detected in 'Tommy Atkins' or 'Keitt' patterns, therefore these seedlings seem to be hybrids of 'Tommy Atkins' and 'Keitt'. One paternal band $(\approx 2.4 \mathrm{~kb})$ did not appear in any progeny. A possible explanation for such pattern is methylation in a restriction site of Hind III that exists in the 'Keitt' genome but does not appear in its offspring, or that this band results from cytoplasmic DNA, which usually is not carried in pollen. Each band in the offspring could be traced back to one of the parents, demonstrating the reliable application of this system for paternity dilemmas.

The results presented in this report suggest that DNA fingerprints in mango are likely to be useful for identification and breeding purposes. The use of various DNA markers' systems in marker assisted selection programs for economically important traits may facilitate selection at a much earlier stage. Moreover, application of these systems might reduce the number of backcross generations needed for introgression of genes into existing cultivars (Hillel et al., 1990). The use of such systems may enhance the prospects for improving mango by detecting and isolating economically important genes for transformation studies.
Campbell, R.J. 1992. A guide to mangos in Florida. Fairchild Tropical Gardens, Miami. Dallas, J.F. 1988. Detection of DNA fingerprints of cultivated rice by hybridization with a human minisatellite DNA probe. Proc. Natl. Acad. Sci. USA 85:6831-4835.

Degani, C., R. El-Batsn, and S. Gazlt. 1990. Enzyme polymorphism in mango. J. Amer. Soc. Hort. Sci. 115:844-847.

Degani, C., M. Cohen, R. El-Batsn, and S. Gazit. 1992. PGI Isozyme diversity and its genetic control in mango. HortScience 27:252-254.

Dunnington, E.A., O. Gal, P.R. Siegel, A. Haberfeld, A. Cahaner, U. Lavi, Y. Plotsky, and J. Hillel. 1991. DNA fingerprints as a method of evaluating relatedness in chickens. Poultry Sci. 70:463-467.

Feinberg, A.P. and B. Vogelstein. 1983. A technique for radiolabeling DNA restriction endonuclease fragments to high specific activity. Anal. Biochem. 132:6-13.

Fritsch, E.P., J. Sambrook, and T. Maniatis. 1989. Molecular cloning: A laboratory manual. 2nd ed. Cold Spring Harbor Univ. Press, Cold Spring Harbor, N.Y.

Gebhardt, C. and F. Salamini. 1992. Restriction fragment length polymorphism analysis of plant genomes and its application to plant breeding. Intl. Rev. Cytol. 135:201-237.

Gazit, S. and A. Kadman. 1980. 13-1 Mango rootstock selection. HortScience 15:669.

Haberfeld, A., A. Cahaner, O. Yoffe, Y. Plotzky, and J. Hillel. 1991. DNA fingerprint of farm animals generated by micro and minisatellite DNA probes. Animal Genet. 22:299-305.

Hillel, J., Y. Plotsky, A. Haberfeld, U. Lavi, A. Cahaner, and A. J. Jeffreys. 1989. DNA fingerprints of poultry. Animal Genet. 20:145-155.

Hillel, J., E.A. Dunnington, and P. B. Siegel. 1992. DNA markers in poultry breeding and genetic analyses. Poultry Sci. Rev. 4 (1991):169-186.

Hillel, J., T. Schaap, A. Haberfeld, A. J. Jeffreys, Y. Plotzky, A. Cahaner, and U. Lavi. 1990. Genomic selection: Application of DNA fingerprints for efficient gene introgression. Genetics 124:783-789.

Jeffreys, A.J. and D.M. Morton. 1987. DNA fingerprints of dogs and cats. Animal Genet. $18: 1-15$.

Jeffreys, A.J., V. Wilson, and S.L. Thein. 1985a. Hypervariable 'minisatellite' regions in human DNA. Nature (London) 314:647-73.

Jeffreys, A.J., V. Wilson, and S.L. Them. 1985b. Individual-specific 'fingerprints' of human DNA. Nature (London) 316:76-79.

Jeffreys, A.J., V. Wilson, S.L. Thein, D.J. Weatherhall, and B.A.J. Ponder. 1986. DNA fingerprints and segregation analysis of multiple markers in human pedigrees. Amer. J. Human Genet. 39: I 1-24.

Kuhnlein, U., Y. Dawe, D. Zadworny, and J.S. Gavora. 1989. DNA fingerprinting: A tool for determining genetic distances between strains of poultry. Theoretical Applied Genet. 77:669-672.

Lavi, U., J. Hillel, A. Vainstein, E. Lahave, and D. Sharon. 1991. Application of DNA fingerprints for identification and genetic analysis of avocado. J. Amer. Soc. Hort. Sci. 116:1078-1081.

Masatoshi, N. and L. Wen-Hsiung. 1979. Mathematical model for studying genetic variation in terms of restriction endonucleases. Proc. Natl. Acad. Sci. USA 79:52695273.

Murray, M.G. and W.F. Thompson. 1980. Rapid isolation of high molecular weight plant DNA. Nucleic Acid Res. 8:4321-4325.

Nurnberg, P., L. Roewer, H. Neitzel, K. Sperline, A. Popperl, J. Hundrieser, H. Poche, C. Epplen, H. Zischler, and J.T. Epplen. 1989. DNA fingerprinting with theoligonucleotide probe (CAC), Somatic stability and germline mutation. Human Genet. 84:7578.

Nybom, H. and B.A. Schaal. 1990. DNA 'fingerprints' applied to paternity analysis in apples (Malus x Domestica). Theoretical Applied Genet. 79:763-768.

Oppenheimer, H. 1978. Subtropical fruit trees and their cultivation in Israel. Am-OvedTarbuth Vehinuch, Tel-Aviv.

Sharon, D., J. Hillel, A. Vainstein, and U. Lavi. 1992. Application of DNA fingerprints for identification and genetic analysis of Carica papaya and other Carica species. Euphytica 62: 119-126.

Shenker M. 1989. Studies on Iron deficiency in mango: uptake mechanisms and new approaches to fertilization (in Hebrew). MS thesis. The Hebrew Univ. of Jerusalem, Faculty of Agr., Rehovot.

Singh, L.B. 1969. Mango, p. 309-327. In: F.P. Ferwerda and F. Wit (eds.). Outlines of perennial crop breeding in the tropics. Veenman and Zonen, Wageningen, Netherlands.

Slor, E. and S. Gazit. 1982. Selection of mango at the Zrifin Experimental Station. Alon Hanotea 36:837-840.

Snedecor, G.W. 1956. Statistical methods applied to experiments in agriculture and biology. The Iowa Stat Colleg Press, Ames. p. 190-193.

Tzuri, G., J. Hillel, U. Lavi, A. Haberfeld, and A. Vainstein. 1991. DNA fingerprint analysis of ornamental plants. Plant Sci. 76:91-97.

Vassart,G., M. Georges, R. Monsieur, H. Brocas, A.S. Lequarre, and D. Cristophe. 1987. A (sequence) of M13 phage detects hypervariable minisatellites in human and animal DNA. Science 235:683-684. 